\title{
人的利用が河川高水敷の地被状態変化に及ぼす 影響の定量的把握方法とその考察 QUANTITATIVE MEASUREMENT AND THE ANALYSIS OF RIPARIAN LANDCOVER CHANGES BY THE INFULUENCE OF HUMAN DISTURBANCE
}

\author{
大石 哲也 1 ・天野 邦彦2 \\ Tetsuya OOISHI and Kunihiko AMANO \\ 1正会員 工修 （独）土木研究所 河川生態チーム 研究員（テ305-8516 茨城県つくば市南原 1-6） \\ 2正会員 工博 （独）土木研究所 河川生態チーム 上席研究員（同上）
}

\begin{abstract}
The purpose of this paper is to examine the trend of the riparian land-cover changes over the past 100 years quantitatively. We have analyzed the land-cover and the height of plants within riparian area in the year of 1890, 1947, 1961, 1974 and 1990 by using maps and aerial photos in the downstream part of Kokai river.

The ratio of land-cover and the height of plants did not change significantly until 1970's, suggesting that riparian environment was in equilibrium. However, the area of the forest increased by $18 \%$ and the height of trees increased up to $15-20$ m from 1970's to 1990's. This can be attributed to the decline of the human disturbance. We have characterized three typical processes which lead to the growth of forest in riparian area in Kokai river, as follows.

1) Reed area was transformed to forest area.2) Trees in forest area have been no longer cut and used as fuel. 3) Cultivation activity has been lowered in riparian area. Above three processes seem to have been accelerated due to the change of the life style of people in the vicinity of the river.
\end{abstract}

Key Words : river flood channel, landcover, human disturbance, GIS, forestation

\section{1.はじめに}

近年，河川では草地や樹林地といった安定的な植生 域が増えてきている. 実際に，この50 年の景観変化を みても，多くの河川で，川幅が縮小するとともに草地, 樹林地が増大してきている11). とくに樹林地の拡大につ いては，治水安全率を大きく低下させる原因にも繋がり， その抑制は河川管理上重要な課題である.

河川に草地や樹林地が増えるプロセスについては, これまで，流れや土砂移動といった水理的作用と植物の 物理的・生理的作用との関係により, その解明が進めら れてきている2,3). これについては，攪乱の主役であっ た洪水が減ったために植物が増えたと単純に考えられる こともあったが，洪水をきっかけに植物が急激に増える パターンがあることもわかるようになってきだ).一方, 流れや土砂移動の影響が少ない箇所についても, 近年, 草地・樹林化が進行してきている. これらは，耕作放棄 や河川管理による樹林伐採の減少など，川へ関わる人為 的攪乱の減少により，これまで抑制されてきた樹木が成 長した結果と考えられる. しかしながら，これらの解明
については，過去から実際に作用した影響を定量的に捉 えることが難しいために，定量的なデータをもとに，十 分な議論が為されていないものと思われる.

そこで本研究では，(1)現況で入手できる資料（迅速 四や国土地理院で撮影された空中写真）をもとに過去 100 年間の地被状態の変遷を明らかにする, (2)空中写真 から草本や樹木の高さを判読し，その変化を明らかにす る，(3)各年のデータを GIS を用いて整理する，という手 順で, 土地利用の変化パターンやその変化量を抽出する ことを目的とした. さらに，得られた結果を踏まえて， 地被状態の変化と人的利用の変化との関係ついて考察を 行った.

\section{2. 研究対象地の概要}

研究対象とした小貝川は, 延長 $112 \mathrm{~km}$, 流域面積 1,043km²の 1 級河川である（図-1）。標高 $187 \mathrm{~m}$ の杤木県 那須郡南那須長大赤根の丘陵地を源流とし，利根川合流 部にあたる茨城県相馬郡利根長町まで流れる．本河川の 特徵は，他の 1 級河川に比較して，平地面積率が大きく， 


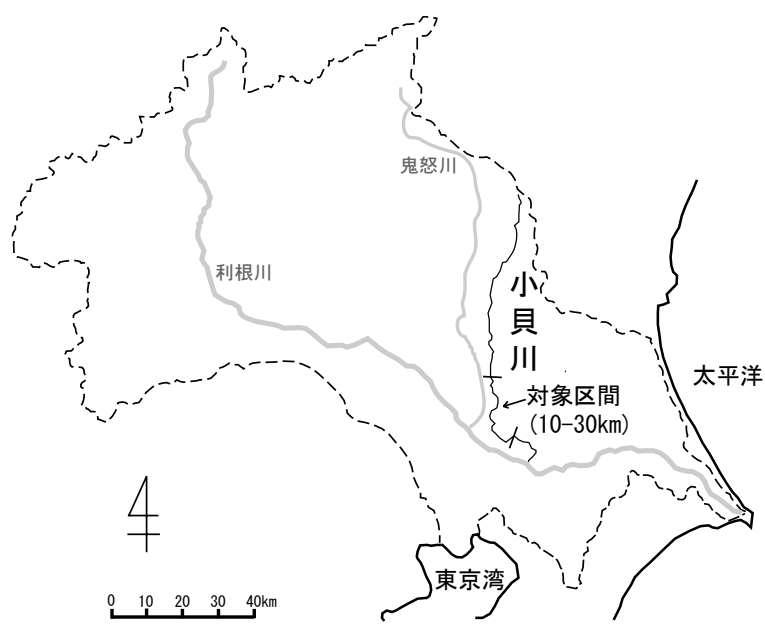

図-1 研究対象地とその周辺の主要な河川
表-1 分類項目とその定義

\begin{tabular}{ll}
\hline 分類項目 & 分類項目の定義 \\
\hline \hline 水域 & 水面である場所 \\
自然裸地 & 植物の繁茂が目立たなく, 人工的利用がな \\
& されていない場所, 主に砂州 \\
人工裸地 & 樋門などの人工的な場所および車両等の侵 \\
& 入で裸地化されていた箇所 \\
耕作地 & 水田, 畑である場所 \\
草地 & 草本植物が繁茂している場所 \\
樹林地 & 木本植物が繁茂している場所 \\
その他 & 凡例不明, 判読不可能（雲の陰りなど）で \\
& ある場所
\end{tabular}

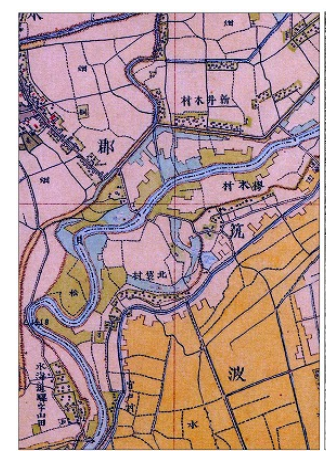

1890 年

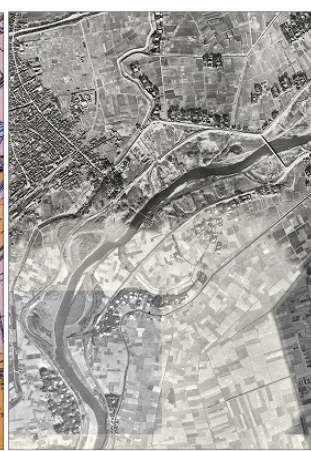

1947 年

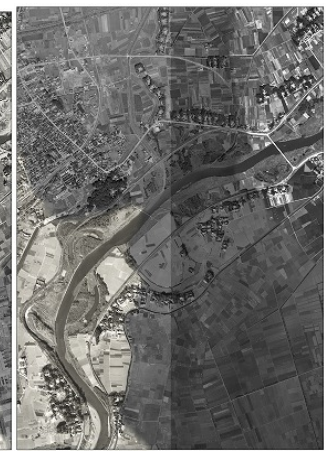

1961 年

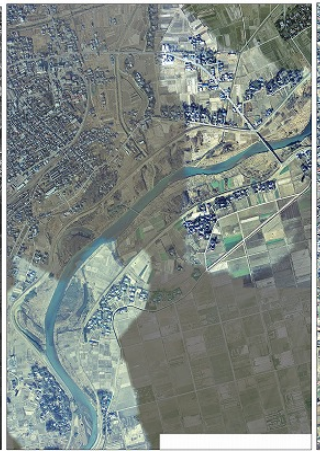

1974 年

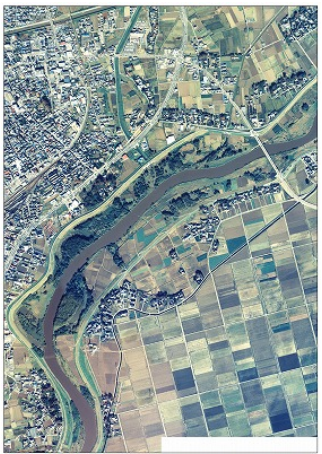

1990 年

図-2 利用した迅速図および空中写真（抜粋）

- 21km〜24m 区間における各年の迅速図および空中写真 -

山地の高度が低いことがあげられる5゙. 近くに鬼怒川と いう砂利採取効率のよい河川があることにより, 河床掘 削がほとんどなされず，このため河床高があまり変化せ ず，位況の経年変化は少ない5.

小貝川は用水利用も目立ち, 関東の 3 大堰として有名 な福岡堰，岡堰，豊田堰があるほか，上流部に 7 ヶ所の 堰があり, 農業用水等に利用されている6).人の暮らしと 密接に関係していたため, 現在でも高水敷上には, 薪炭 林の残存であるクヌギ，コナラの高木が目立つ.ただし， 近年, それらの樹種は, 河畔の代表的な樹種であるヤナ ギやハンノキに置き換わられつつある.

調査対象区間は，小貝川の河川管理区間である $10 \mathrm{~km}$ から 30km までとした（図-1）。なお，小貝川の場合， $0 \mathrm{~km}$ 地点は利根川との合流部付近ではなく, そこから約 $5 \mathrm{~km}$ 上流にある. 河床勾配は, 約 $50 \mathrm{~km}$ 上流にある黒子橋 付近で大きく変化し，橋の上流側が $1 / 500$, 下流側が 1/4,000 となる. 本検討で対象とした地区は, 河床を砂 分が多く占める下流部にあたる. 流域形状の特性を反映 して, 出水による大きな河道変化がないため, 高水敷の 地被状態の変化は，主に人為的な影響によるものである. そのため, 人為的攪乱による河川高水敷の地被状態の変 遷を定量的に理解しや寸いモデル的な場所とも考えられ る.

\section{3. 利用データと解析方法}

\section{(1)地被状態の GIS 化}

迅速図（1890 年）, 空中写真（1947 年, 1961 年, 1974 年，1990 年）から GIS を用いて地被状態情報を抽 出し，1 つの空間座標系に統合した（図-2）. 迅速図に ついては, 土地利用の凡例をもとに, 水域・自然裸地・ 人工裸地・耕作地・草地・樹林地の 6 項目に分類し, ポ リゴン・データ化を行った. このデータを 1890 年の土地 利用データとした.

空中写真は, 迅速図で分類した項目を参考に, 表-1 に示寸定義に基づき判読しポリゴン・データ化を行った. なお，凡例不明，判読不可能である場所は，迅速図，空 中写真とも「その他」とした. 以上の処理により, 迅速 図や空中写真から地被状態を数值情報化することで GIS による定量的分析を可能にした.

\section{(2) 表層高の読み取りと草地・樹林高の算出方法}

図化機を用い空中写真を立体視することにより地物 の高さを求める方法で, 表層高情報を取得した. 読み取 り区域は, 約 1 ha $(100 \mathrm{~m} \times 100 \mathrm{~m})$ 内とし, 区域内におけ る表層高を判読した（図-3）。本研究では代表的な区域 


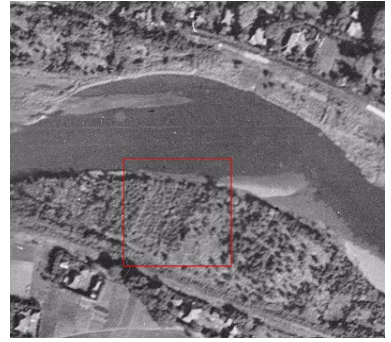

1947 年

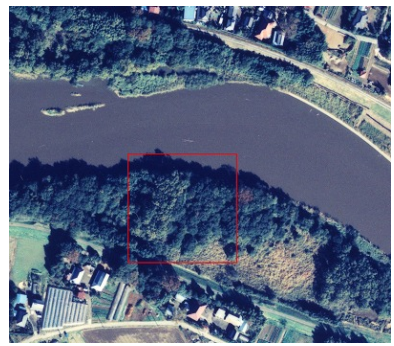

1990 年
図-3 表層高の抽出に選んだ区域（抜粋 : 右岸 $23 \mathrm{~km}$ ) 一ロで囲まれた区域（約 1ha）の表層高を図化機により判読一

を 4 箇所のみ選定している. 読み取りに当たっては，当 該箇所の草や樹木といった地物の表層高を約 $0.5 \mathrm{~m}$ 間隔 で読み込み，ポイント・データに変換したのち，TIN

(Triangulated irregular network) 処理により起伏デタを作成した. さらに，この起伏データを基に $1 \mathrm{~m}$ 格子の Grid データに区分することにより，各 Grid に標高值を与 えた．なお，水面や堤防にかかる領域はデータから除外 した.

取得された表層高を元に地盤高との差分により草 地・樹林の地物高を算出した。地盤高については，2003 年に取得されたプロファイラ・データ7を TIN 処理したも のを用いた。作成された地盤高と定期横断測線図を比べ ると，当該地区の基盤高は昭和初期から現在までに大き な変化はなかったため，ここでは本処理データを各年の 基準の地盤高とし，地物高の算出に用いた。

\section{4. 結果}

\section{(1)地被状態の経年的な変化}

図-4に調査対象区間における堤間区域の地被状態の 経年的な変化を示寸。

1890 年は，耕作地や樹林地の面積が 40\%を超えるなど， 他年と比較し，その割合が多い．松や雑木（クヌギ，コ ナラなど）が多く，小貝川の高水敷は生活利用されてい たことが迅速図から伺える，ただし，地図上の地被状態 については，松や雑木がどの程度の密度であったかは確 認できないことや写真と比較すると情報が簡素化される 分だけその割合も正確性に欠ける。しかし，これ以上詳 しいデータは現存しないため, ここでは 1890 年の地被 状態と見な寸が，あくまでも参考程度として理解された い.

1947 年では, 耕作地や樹林の占める割合が減少し, 代わりに草地の占める割合が大きくなった。 1961 年, 1974 年ともに, 耕作地の面積が多少変化しているもの の 1947 年と大きな差異は見られない. なお，自然裸地 や水域の場合，写真撮影前の降雨状況により両者の割合 は大きく変化する可能性がある. したがって，水域と自

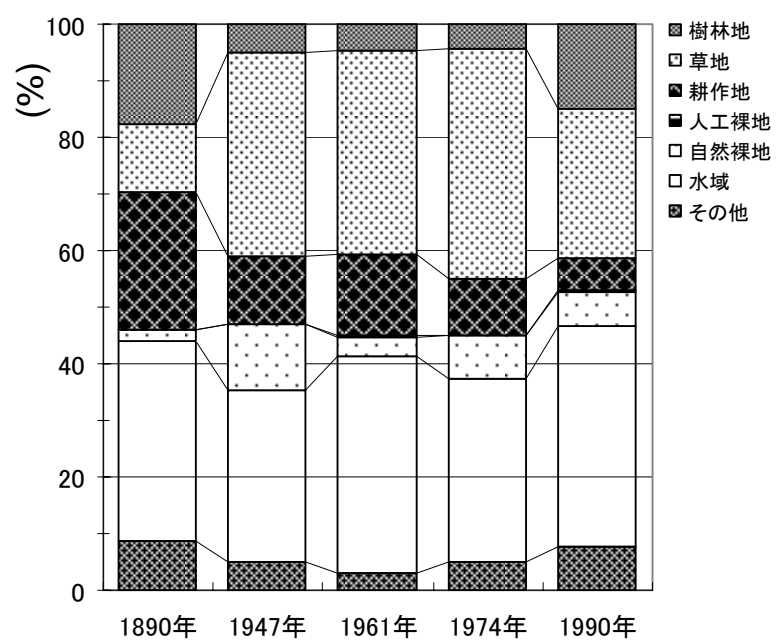

図-4 各年における地被状態

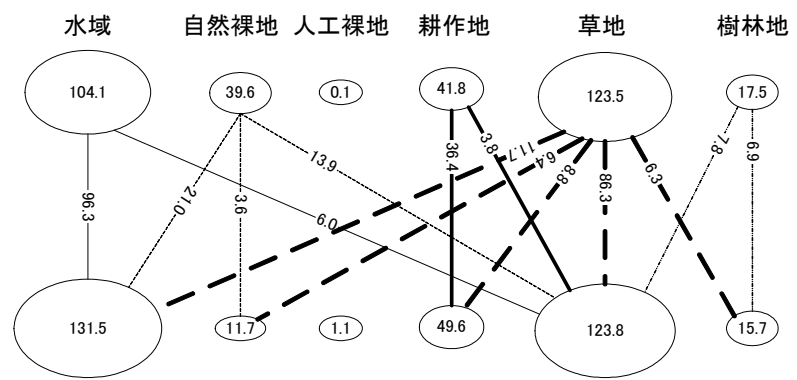

期間(1) 1947年 $\rightarrow 1961$ 年

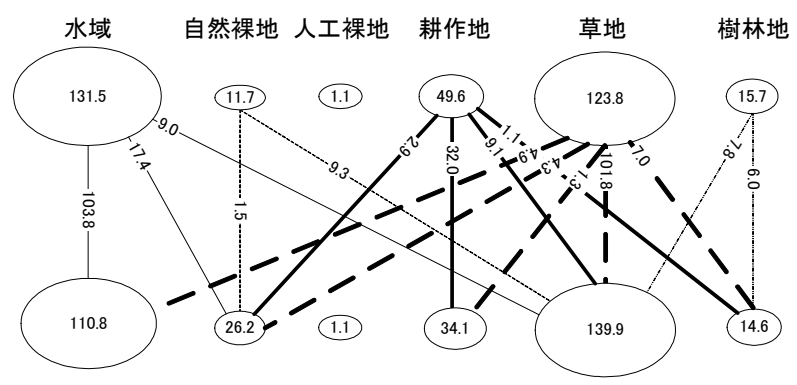

期間(2) 1961年 $\rightarrow 1974$ 年

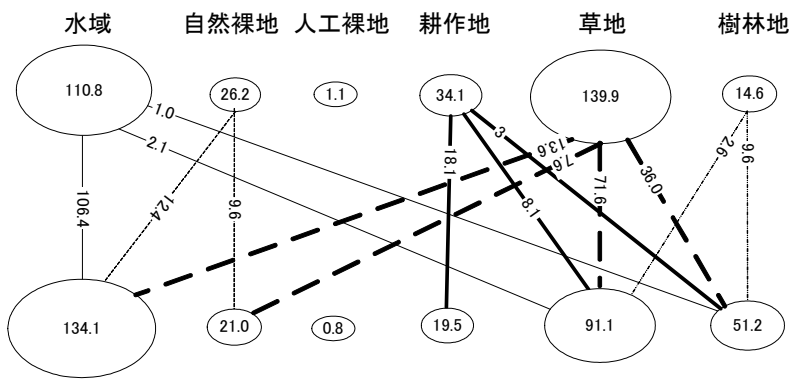

期間(3) 1974年 $\rightarrow 1990$ 年

図-5 期間別にみた地被状態の変化パターン 一表中の数字は面積（ha）を示すー

然裸地域に限っては，人為影響の及ばない箇所として， ひとくくりの情報として考える方が妥当と言える.

1990 年になると，地被状態が大きく変化した．その 傾向を見ると，草地・耕作地が減少し，逆に樹林地の割 合が増加した。その割合は，1974 年からの 16 年間で樹 
林割合が 3 倍まで増え $18 \%$ となった。

\section{(2) 土地利用の変化パターン}

図-5 に土地利用の変化パターンを示寸。楕円内の数 字は，読み取りから得られた各地被の面積（ha）を示し ている. 図の上部が下部よりも古い年であり, 古い年を 基準とし新しい年へ向かっての地被状態の変化を線で結 んでいる. 線内の数字は，上部から下部へ向かい同一あ るいは別の地被状態へ変化した面積を示している。 なお， 1890 年のデータは, 他と比較し正確性に欠けるため, ここでは比較検討から除いた．また，地被状態が「その 他」である箇所も主要な変化パターンとして検討できな いため, 検討外とした.

1947 年から 1961 年 (期間(1) にか忖て, 耕作地のほ とんどはそのまま耕作地として維持されており，草地一 の転換も若干見られる．草地は，主として草地のまま維 持されているが, 耕作地一約 9ha, 樹林地一約 6ha へと 変化していた. また，樹林地は，半分よりやや少ない面 積が樹林地のままであるが，残りが草地へと変化してい た. 1961 年から 1974 年（期間(2)）にかけては，期間(1) での傾向とほぼ同等と見なしてよく，例えば，草地と樹 林地との間の変化については, 変化面積がほぼ同じであ った. 一方，1974 年から 1990 年（期間(3)）にかけては, 期間(1)，期間(2)と比較寸ると，その変化の傾向は異なっ ていた．とくに，これまで，草地と樹林地で約 $7 \mathrm{ha}$ 前後 の面積が入れ替わっていたものが，草地から樹林地へと 変化する面積が 36 ha と大きくなり, 樹林地から草地一 と変化する面積は約 3ha と小さくなっていた．また，樹 林地のまま維持される面積は約 10ha と大きくなってい た. 期間(3においては，草地であった箇所が樹林地へと 変化する傾向が強まり, 樹林一と遷移が進行しているこ とが伺えた。

\section{（3）地物高（草本高 - 樹林高）の変化}

ここでは，樹林化と関連するとみられる典型的な変 化について，高さ情報を利用して検討寸る．図-6に樹 林化に関わる典型的な 4 つのパターンを示した箇所にお ける地物高とその密度との関係を示す，なお，ここでは 地物高の結果以外にも当該箇所の迅速図での凡例や 2007 年に植生調査を行ったので，100 年前から現在まで の地被状態の変化について定性的な記述も加えた.

\section{a）草地が近年になり樹林地となるパターン}

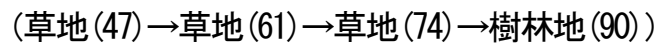

右岸の $17 \mathrm{~km}$ 付近にあたり，迅速図ではヨシ原であった 箇所が，2007年には，ムクノキーエノキ林が優占してい る。図-4，図-5にもみられるように，草地が減少し，樹 林地が増加するパターンは, 主要パターンの1つとしてあ げられる.

地物高の変化をみると，1947 年には中央值で約 $2 \mathrm{~m}$ で あり，1〜2m の地物高の占める割合が高い. 1961 年は,
中央值が $1 \mathrm{~m}$ 末満であり，1〜4m にかけて幅広く分布し ていた. 1974 年には，大部分は地物高 1 2mであるが, 10m を超える地物高もわずかにみられた. 1990 年には, 中央值で約 $11 \mathrm{~m}$ であり，全体的に高木林が目立つように なった．他年と比較し大きな地物高（樹林）が目立ち, 地物高が 9m〜 14m の間において，どの高さも密度が 10\% 前後であった.

\section{b）草地が 30 年以上前に樹林地となっていたパターン}

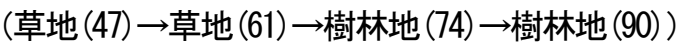

右岸の $23 \mathrm{~km}$ 付近にあたり, 迅速図ではヨシ原であっ た箇所が，2007 年には，ムクノキーエノキ林が優占し ている。

地物高の変化をみると，1947 年には，0～2m の地物高 が全体の 90\%以上を占めていた。 中央值が $1 \mathrm{~m}$ というこ とからみても，背丈の小さな草本が優占していたものと 思われる. 1961 年になると, 徐々に地物高が高くなり, $2 \mathrm{~m}$ が分布の中央となる. 大部分はヨシやオギといった 高茎草本と考えられる．また，密度は僅かだが，最大で $7 \mathrm{~m}$ の高さもみられることから，孤立の樹木があったも のと思われる. 1974 年には，平均值，中央值とも $6 \mathrm{~m}$ 前 後であり，樹林が目立つようになった。 1990 年になり， 12-15m 付近だけで全体の約 80\%を占めるなど，高木の樹 林地が目立つようになった。

\section{c）過去より樹林地のまま推移したパターン} (樹林地 (47) 一樹林地 (61) 一樹林地一樹林地 (90))

左岸の $22 \mathrm{~km}$ 付近にあたり，迅速図では松林であった箇 所が，2007年にはクヌギ林が優占している。

空中写真による地被状態の変化から, 1947 年から 1990 年にかけて樹林地である箇所だが，地物高（樹 林）には大きな変化がみられた.

地物高の変化をみると，1947 年には中央值が約 $5 \mathrm{~m}$ で あり，4m〜6m の低木林が大部分を占めていた． 1961 年 には，中央值が約 $3 \mathrm{~m}$ になり，この期間中に刈り取りが 行われていたものと推察される.1974 年になり, 中央 值が $8 \mathrm{~m}$ を超え， $7 \mathrm{~m} \sim 9 \mathrm{~m}$ の亜高木林が多く占めるように なった． 1990 年には，中央值が約 $14 \mathrm{~m}$ になり高木林が多 く占めるようになった.

\section{d）耕作地が草地になったパターン}

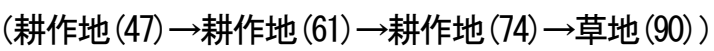

左岸の $24 \mathrm{~km}$ 付近にあたり, 迅速図では畑地だったが, 2007年には，草本にセイタカアワダチソウ，八ナムグラ， オギ，カナムグラなど，樹林にタチヤナギ，スギ・サワ ラなどが混成している.

地物高の変化をみると，1947 年から 1974 年にかけて は，耕作地であるため，地物高も低い. 1990 年に耕作 地から草地一変化したが，地物高に大きな変化はみられ なかった.この理由として，1990 年の段階では，放棄 されてから数年ほどしか経ていない可能性がある。つま り, 1981 年, 1986 年の 2 度に渡る大きな出水を境に, 耕作放棄地が増えたのが一因と思われる。 


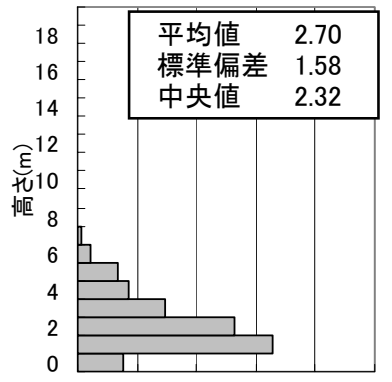

$0 \% \quad 10 \% \quad 20 \% \frac{2}{\text { 密度 }} \quad 30 \% \quad 40 \% \quad 50 \%$

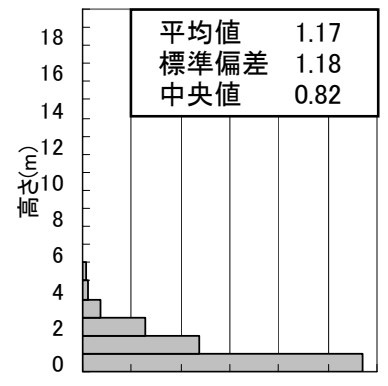

$\begin{array}{llllll}0 \% & 10 \% \quad 20 \% & 30 \% & 40 \% \quad 50 \% \quad 60 \%\end{array}$

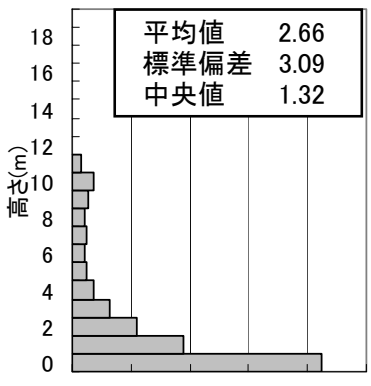

$0 \% \quad 10 \% \quad 20 \% \frac{\text { s }}{\text { 空度 }} 30 \% \quad 40 \% \quad 50 \%$

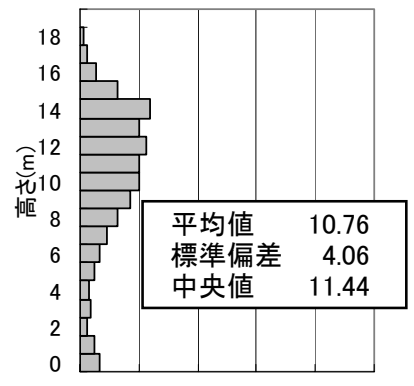

$0 \% \quad 10 \% \quad 20 \% \frac{\text { 密度 }}{30} \quad 40 \% \quad 50 \%$

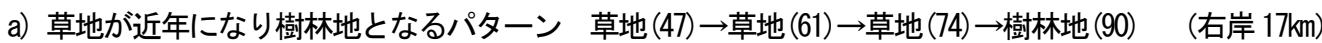
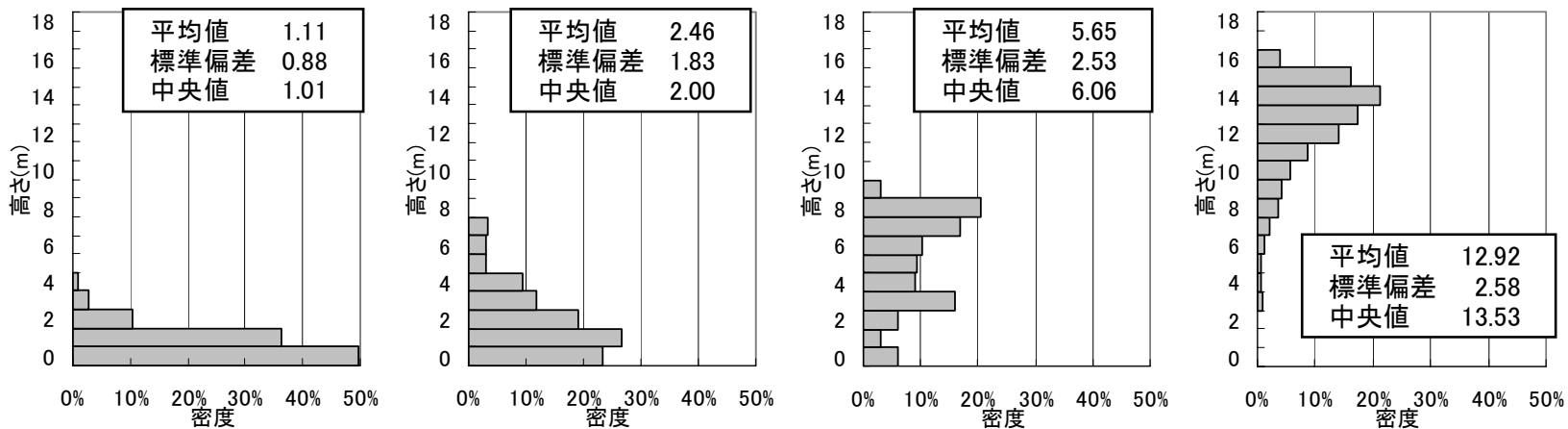

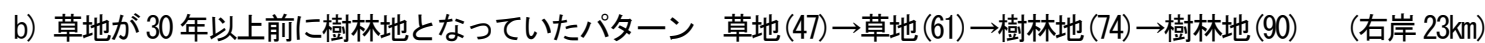

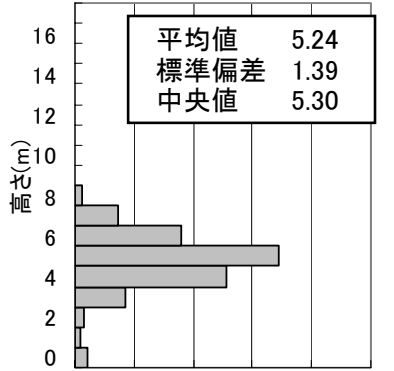

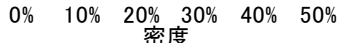

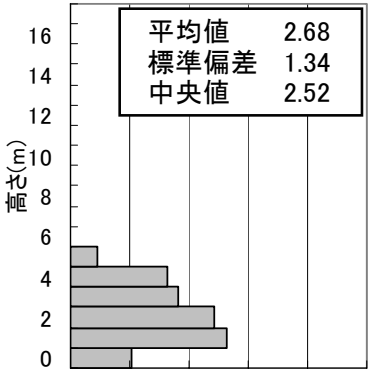

$\begin{array}{llllll}0 \% & 10 \% & 20 \% & 30 \% & 40 \% & 50 \%\end{array}$

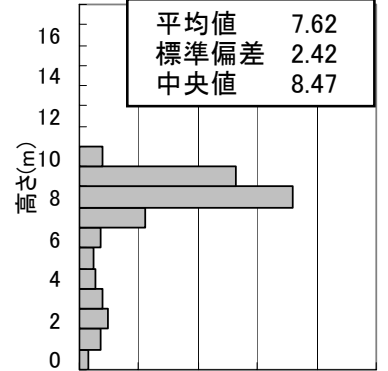

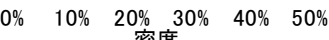

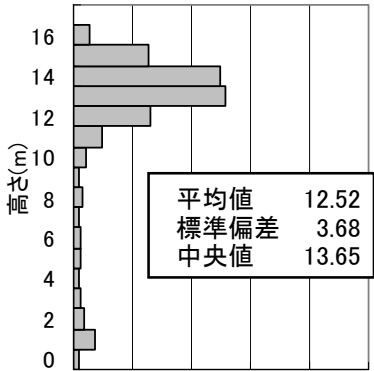

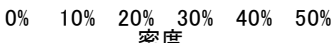

c）過去より樹林地のまま推移したパターン＼cjkstart樹林地 (47) 一樹林地 (61) 一樹林地 (74) 一樹林地 (90) （左岸 22km)
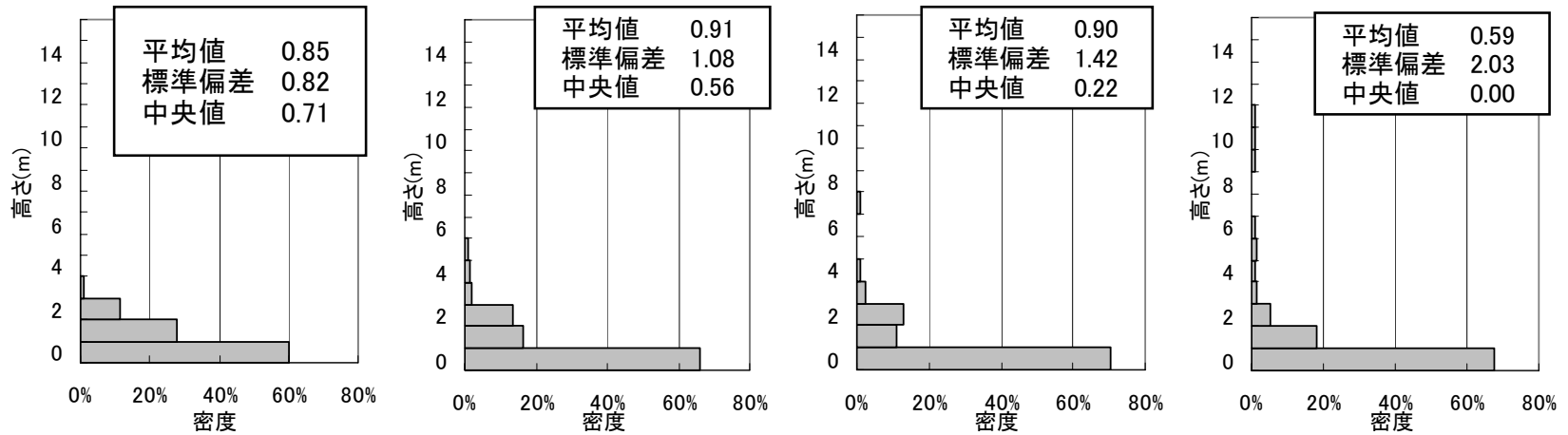

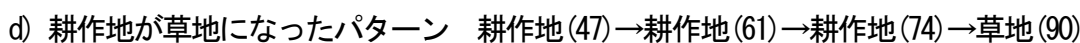

（左岸 24km）

図-6 各年の地物高分布之密度との関係

以上のように，管理が行き届いた土地では，時間が

経ても地物高が高く成り得ないが，放置してから約 15

年も経ると樹林が目立つようになるようである.

\section{5. 考察}


本研究では, 現存する迅速図や空中写真を用いて, 人的利用の変化が河川高水敷の地被状態へ表れることを 定量的に把握した. 1940 年代から 1970 年代までにかけ ては，各地被面積の割合はほぼ一定であったが，その内 訳をみると草地が樹林地に変化したり，また戻ったりし ていた．これらの変化は，収支バランスがとれており， 人の生活に密着し持続的に管理されていたことが伺えた。 1970 年代以降になると, 生活様式の変化により, 河川 を生活の一部として利用しなくなり，一方的な変化が始 まった，それは，樹林面積の拡大と樹木高の増加であっ た．樹木高については，管理放棄を始めて約 15 年も経 ると 15〜20mほどの高木林へと変化していた。 このよ うに人為の影響が少なくなれば，植物の自然的な遷移に 従い，程度の違いはあるが 10 年〜20 年のうちに本河川 は樹林化へと進行することが言える.

地物高の変化の検討から, 樹林化の傾向については, 3 つの傾向があることが考えられた．1つ目は，草地か ら樹林地一と変化するもので，かつてヨシ原であった箇 所が樹林一至るパターンである.ヨシ原は，根莫き，垣 根，よしず，あるいは燃料，肥料などに利用されていた が，現在では，その利用のための刚り取りや火入れが行 われなくなり，樹林地の増加に繋がったと考えられる. 本河川の場合, その傾向は早い箇所で, 1974 年には表れ ていた。

2 つ目は，樹林地であった箇所の樹木が高木化したり， 樹林地が拡大寸るパターンである。これは，マツ，クヌ ギ，コナラの薪炭林が利用されなくなった結果，樹木の 高木化や樹林地の拡大に繋がったものと考えられる.こ の理由として，河川においても里山管理と同じように, 15〜25 年に 1 度は薪炭林の更新のため伐採する ${ }^{8)}$ という 生活様式が消㓕したことによる影響が大きいと思われる。 また，1970 年以降は，河川管理上，治水安全率を維持 するための樹林伐採が樹木の抑制につながっていたが, これが最近減少してきた結果が表れているものと推察さ れる。

3 つ目は，耕作地であった箇所が放棄された結果，草 地化一と進行し，15〜20 年後には，樹林地一の増大が 懸念されるパターンである. 以上の 3 つのパターンは, すべて生活様式の変化を反映したものである. 例えば, カヤ場（ヨシ原）の減少は茅莫き屋根からトタンや瓦屋 根へと変化した結果であるし，薪炭林放棄は，燃料が木 炭から石油，ガスへと変化した結果である．さらに，第 一次産業の衰退にともなう耕作地の減少は，近年，堤内 地においても多く見られるようになってきた社会現象の 一端であり，今後河川の樹林化を促進する可能性が高い，

これらの生活様式の変化は, 地被状態の変化に与える だけでなく，地域の河川生態系にも影響を及ぼしている 可能性が高い，一例をあげれば，ヨシ原に依存する才才 ヨシキリや林床内のフジバカマの減少なども生活様式の 変化に起因寸る現象とも考えられる.

\section{6. おわりに}

本研究で，河川環境は流域の生活との関わりが深い ことが定量的にデータから示唆された．昨今，川の本来 の姿や河川の健全性が議論されることが多くなった。 そ れらの議論の中には，河川管理の結果，環境が劣化して いるので，これまで行っていた管理を低減し，河川の夕゙ イナミクスを復元することで河川環境の修復を目指すと いう考え方が強く働いているケースが多く見られる．河 川のダイナミクス復元の観点は非常に重要であり，基本 的な考え方であるが，我が国の河川において，特に陸域 環境は周辺住民の生活に伴う人為的摚乱に大きく影響を 受けてきており，このような擋乱が減少した現在，河川 環境を動的平衡状態に維持するには，河川のダイナミク ス復元に加えて，過去の人為的擋乱に相当する擋乱を計 画的に加える必要があると考えられる.

河川環境を知るためには，本研究でも示したように， 現存する資料を整理し，過去から現在までに河川環境が 種々の作用に対応してどう変化してきたのかといったこ とを捉えることがまずは重要と考える．それを基に河川 環境を議論することで，種々の作用の結果として見える 過去を単に模倣するのではなく，過去を参考としながら， 将来の河川環境の姿を捉え，河川をどのように管理して いくのか目標も立てや寸くなるものと思われる.

\section{参考文献}

1）大石哲也，萱場祐一，天野邦彦：全国 7 河川の河道特性及 び地被の長期変動の実態とその関連性，河川技術論文集， Vol.11， pp. 367-362，2005.6.

2）藤田光一, 李参熙, 渡辺 敏, 塚原隆夫, 山本晃一, 望月達 也：扇状地砂床河道における安定植生域消長の機構とシミュレ ーション，土木学会論文集，№. 747/II-65，pp.41-60， 2003.

3）李参熙，藤田光一，山本晃一：磼床河道における安定植生 域拡大のシナリオ,一多摩川上流部を対象にした事例分析によ り-，水工学論文集，Vol.43，pp.977-982，1999.

4）藤田光一: 河原での植物と洪水のせめぎ合いを計算する, 辻本哲朗監修・ (財) 河川環境管理財団編，川の技術のフロン 卜, pp. 164, 2007.7

5）山本晃一：河道・環境特性情報の読み方と利用一事例研究を 通じて-，河川環境総合研究所資料，Vol. 18，2007.2.

6）鬼怒川・小貝川サミット会議：鬼怒川・小貝川一自然 文化 歴史，鬼怒川・小貝川サミット会議（下館工事事務所）， 1993. 3

7）国土技術政策総合研究所危機管理技術研究センター水害研 究室，国際航業株式会社：航空レーザを用いた利根川等の河道 測量業務報告書, 2003.

8）宮脇昭: 日本の植生, 学研研究社, 1977.

(2007. 9. 30 受付) 